Malaysian Journal of Social Sciences and Humanities (MJSSH), Volume 6, Issue 11, (page 1 - 14), 2021

DOI: https://doi.org/10.47405/mjssh.v6i11.1162

\begin{tabular}{|c|c|}
\hline 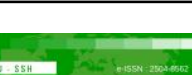 & Malaysian Journal of Social Sciences and Humanities (MJSSH) \\
\hline Malaysian Journal of & Volume 6, Issue 11, November 2021 \\
\hline $\begin{array}{l}\text { Humantites } \\
\text { (MJ. SSH })\end{array}$ & e-ISSN : 2504-8562 \\
\hline & $\begin{array}{l}\text { Journal home page: } \\
\text { www.msocialsciences.com }\end{array}$ \\
\hline
\end{tabular}

\title{
Pembelajaran dalam Talian Sepanjang Pandemik Covid-19: Faktor Akses Internet dan Sosioekonomi Terhadap Motivasi Pelajar Kolej Komuniti
}

\author{
Siti Khadijah Mohd Razali' ${ }^{\text {, Norzaini Azman }}{ }^{1}$ \\ ${ }^{1}$ Fakulti Pendidikan, Universiti Kebangsaan Malaysia (UKM), Malaysia \\ Correspondence: Siti Khadijah (p103767@siswa.ukm.edu.my)
}

\begin{abstract}
Abstrak
Kajian kes ini dijalankan untuk mengkaji tahap motivasi berdasarkan akses internet dan faktor sosioekonomi dalam kalangan pelajar di sebuah kolej komuniti yang terletak di Pahang. Pengkaji melihat empat objektif utama iaitu mengenal pasti tahap motivasi pelajar, perbezaan tahap motivasi berdasarkan faktor jantina, tahap kelajuan internet dan tahap sosioekonomi. Dengan menggunakan kaedah tinjauan, borang soal selidik telah diedarkan secara atas talian (google form) sebagai instrumen bagi memperoleh data berbentuk kuantitatif. Kajian ini mengadaptasi instrumen Motivation Strategies for Learning Questionnaire (MSLQ) oleh Paul Pintrich et al. (1991) bagi mengukur tahap motivasi responden. Selain itu, data demografi berkaitan sosioekonomi dan akses terhadap Internet turut dikumpulkan. Kaedah persampelan rawak mudah digunakan dan seramai 127 orang pelajar kolej komuniti telah dipilih sebagai sampel kajian. Dapatan kajian mendapati motivasi pelajar berada pada tahap tinggi semasa pembelajaran dalam talian sepanjang pandemik. Analisis ujian t bagi tahap motivasi berdasarkan jantina menunjukkan perbezaan yang signifikan di mana motivasi pelajar perempuan adalah lebih tinggi berbanding pelajar lelaki. Analisis ANOVA menunjukkan tiada perbezaan yang signifikan bagi tahap motivasi pelajar berdasarkan pencapaian akademik, kelajuan internet dan tahap pendapatan keluarga. Manakala, tahap motivasi berdasarkan jenis pekerjaan bapa dan ibu menunjukkan perbezaan yang signifikan. Dapatan kajian memberi implikasi kepada pensyarah dan pihak pengurusan kolej komuniti untuk memastikan keperluan asas pembelajaran pelajar diberikan perhatian bagi memastikan proses pembelajaran secara dalam talian dapat dilaksanakan dengan berkesan.
\end{abstract}

Kata kunci: motivasi, sosioekonomi, akses internet, pembelajaran dalam talian

\section{Online Learning Throughout Covid-19 Pandemic : Internet Access And Socio- Economics Against Motivation On Community College Student}

\begin{abstract}
This case study was conducted to examine the level of motivation based on internet access and socioeconomic background among students in a community college located in Pahang. Four main objectives were stipulated to ascertain the level of student motivation, the differences in the level of motivation based on gender, internet speed and the socioeconomic backgrounds. Using a survey method, the study employed a set of questionnaire that was distributed online (using google form) to obtain quantitative data. This study adapted the Motivational Strategies for Learning Questionnaire (MSLQ) instrument by Paul Pintrich et al. (1991) to measure the level of motivation. In addition, data related to respondents socio - economic backgrounds and access to the internet were also collected.
\end{abstract}


The random sampling method was used to determine the sample and a total of 127 students was selected as a sample of the study. The findings show that the level of student motivation was high during the online learning throughout the pandemic. The t-test analysis showed a significant difference between motivation level and gender whereby female students had higher motivation level than the male students. Finding from the ANOVA test showed that motivation was not found to be significantly different based on academic achievement, internet speed and family income. On the other hand, findings showed that there was as significant difference between motivation level and parents occupation. The findings have implications to the college community lecturers and managers in their efforts to provide basic learning basic needs to their students in oder to ensure that online learning process can be implemented effectively.

Keywords: motivation, socio-economic, internet networks, online learning

\section{Pengenalan}

Pandemik Covid-19 yang melanda Malaysia telah mendorong kerajaan melaksanakan arahan Perintah Kawalan Pergerakan (PKP) yang pertama pada 18 Mac 2020 untuk membendung penyebaran wabak tersebut (Muzaffar, 2020; Azman \& Abdullah, 2021). Walaupun terdapat ura-ura yang perintah tersebut akan ditamatkan pada 31 Ogos tahun lalu, PKP masih berlarutan hingga ke September 2021 disebabkan angka kes covid-19 yang terus meningkat. Situasi ini telah memberi kesan kepada hampir kesemua sektor perkhidmatan di Malaysia, termasuk sektor pendidikan. Hal ini mengubah cara pembelajaran secara bersemuka kepada pembelajaran dalam talian. Perihal yang sama juga berlaku di luar negara. Pendidikan dalam talian telah menjadi pilihan bagi kebanyakan negara yang terkesan akibat Covid-19 (Moawad et al., 2020). Norma baharu ini telah memberikan impak yang sangat tinggi kepada dunia pendidikan serta individu yang terlibat (Chung \& Mohamed Noor 2020; Azman \& Absullah, 2021).

UNESCO melaporkan statistik yang amat membimbangkan iaitu seramai $87 \%$ daripada pelajar di seluruh dunia terkesan akibat Perintah Kawalan Pergerakan di negara masing-masing (Ahmad Alif, 2020). Hal ini disebabkan oleh kekangan akses Internet, terutamanya di kalangan mereka yang berpendapatan rendah dan kurang berkemampuan untuk menampung kos internet yang agak tinggi setiap bulan (Nor Musfirah, 2021; Shusmita et al., 2020; Awal et al., 2021; Andrew et al., 2020; Mahiswaran et al., 2020). Dalam hal ini, ramai ibu bapa lebih cenderung membelanjakan wang mereka bagi barangan keperluan hidup seperti makanan, sewa kediaman dan simpanan kecemasan. Mereka juga berdepan dengan pelbagai masalah berkaitan kewangan dan urusan keluarga. Situasi sebegini telah sedikit sebanyak mengganggu proses pembelajaran dan motivasi pelajar semasa pandemik (Mahathir \& Waedatul, 2021; Mohammad Arid \& Sa'odah, 2019).

Motivasi merupakan penggerak, kekuatan dan keperluan yang mendorong seseorang untuk mendapatkan sesuatu perkara yang diinginkan. Proses dalaman (internal) dan luaran (eksternal) sangat berkait rapat dengan motivasi individu bagi mewujudkan kehendak yang berterusan. Dalam konteks pembelajaran matlamat, minat dan usaha ialah faktor penggerak utama motivasi intrinsik, manakala kewangan, ganjaran, pensyarah, keluarga, rakan dan persekitaran merupakan faktor penggerak utama kepada motivasi ekstrinsik. Kedua-dua motivasi ini memainkan peranan yang penting dalam proses pembelajaran pelajar (Nur Syazana et al., 2020; Alhaadi \& Norimah, 2019). Dalam pembelajaran norma baharu, pelajar perlu berdikari, mempunyai kemahiran belajar secara kendiri dan meningkatkan usaha bagi mendapat pencapaian akademik yang baik (Sushmita et al., 2020; Martijin, 2020).

Tujuan utama kajian ini adalah mengenal pasti tahap motivasi pelajar dan kaitannya dengan akses internet dan faktor sosioekonomi keluarga. Kajian ini telah dijalankan di sebuah kolej komuniti di daerah Bentong, Pahang semasa perlaksanaan pembelajaran dalam talian ketika pandemik Covid-19. Pengkaji telah mengenal pasti empat objektif kajian iaitu;

i. Mengenal pasti tahap motivasi pelajar semasa pembelajaran dalam talian sepanjang pandemik. 
ii. Mengenal pasti perbezaan tahap motivasi pelajar berdasarkan jantina dan pencapaian akademik semasa pembelajaran dalam talian sepanjang pandemik.

iii. Mengenal pasti perbezaan tahap motivasi pelajar berdasarkan kelajuan internet semasa pembelajaran atas talian sepanjang pandemik.

iv. Mengenal pasti perbezaan tahap motivasi pelajar berdasarkan faktor sosioekonomi semasa perlaksanaan pembelajaran atas talian sepanjang pandemik.

Artikel ini terbahagi kepada empat bahagian. Bahagian pertama merungkaikan tinjauan literatur kajian lepas yang berkaitan dengan tema dan fokus kajian. Bahagian kedua menerangkan metodologi kajian dan kaedah pengumpulan dan analisis data. Seterusnya, hasil kajian dibincangkan berdasarkan dapatan kajian-kajian lepas dan bahagian keempat kesimpulan yang menjelaskan implikasi dan cadangan kajian lanjutan berkaitan akses internet, sosioekonomi dan motivasi pelajar kolej komuniti.

\section{Sorotan Literatur}

\section{Pembelajaran Dalam Talian Semasa Pandemik Covid-19}

Pembelajaran dalam talian merupakan satu bentuk pembelajaran jarak jauh yang mula diaplikasikan dalam sistem pendidikan di Amerika dan semakin berkembang kebelakangan ini (Nguyen, 2015). Pembelajaran dalam talian merangkumi kemudahan dan kemajuan teknologi bagi menyampaikan pembelajaran, kandungan pembelajaran dan merancang pengajaran (Mukhtar et al., 2021). Penggunaan peranti media membantu pendidik untuk mempelbagaikan kaedah pengajaran seperti menyampaikan pembelajaran melalui video dengan lebih menarik (Khadijah et al., 2020). Kaedah pembelajaran baharu ini memerlukan kemudahan peranti elektronik dan capaian internet bagi membolehkan pelajar mengakses platform tertentu seperti Zoom, Google Classroom, Microsoft Team, Webex, Telegram, WhatsApp (Mazidah \& Nor Aidawati, 2021). Kajian ini akan melihat pembelajaran dalam talian sepanjang pandemik Covid-19 menerusi motivasi, akses internet dan sosioekonomi keluarga pelajar.

\section{Motivasi}

Motivasi merupakan aspek penting dalam memastikan pembelajaran yang berkesan dan bermakna. Motivasi dapat mengekalkan, meningkatkan dan mengawal minat individu (Bernard, 1965). Motivasi juga dinyatakan sebagai desakan yang membantu individu untuk bergerak atau bertindak dalam sesuatu perkara (Crow \& Crow, 1981). Motivasi mampu memberikan kesan positif terhadap diri individu terutamanya dalam proses pembelajaran sebagai persediaan seseorang dalam memperoleh kemajuan (Matsumoto, 2009).

Umumnya, motivasi dibahagikan kepada dua iaitu motivasi intrinsik dan motivasi ekstrinsik. Menurut Feldman (1994) motivasi intrinsik ialah aktiviti yang dilakukan untuk memperoleh kepuasan manakala motivasi ekstrinsik adalah untuk mendapatkan ganjaran. Motivasi intrinsik merupakan motivasi yang dihasilkan daripada dorongan dalam individu tanpa faktor luar mempengaruhinya. Motivasi jenis ini lebih menekankan kepada perasaan, proses dan juga pengalaman individu. Manakala motivasi ekstrinsik pula merupakan faktor-faktor yang diperoleh daripada rangsangan luar dan persekitaran seperti pujian, ganjaran, populariti dan galakan daripada individu lain. Motivasi manusia boleh ditingkatkan dengan beberapa langkah, pertama dengan menerima motivasi sekeliling, kedua dengan memahami sendiri unsur motivasi tersebut dan ketiga melalui penglibatan aktif (McClelland, 1978; Oxford \& Shearin, 1994).

Beberapa kajian lepas telah menunjukkan bahawa motivasi pelajar semakin menurun semasa pembelajaran dalam talian sepanjang pandemik Covid-19 dilaksanakan (Siti Nurshahidah et al., 2020; Martijn, 2020). Kajian oleh Siti Nurshahidah et al. (2020) menyatakan pelajar IPT tidak dapat menguruskan isu dalaman (faktor kognitif), isu luaran (faktor persekitaran) dan isu motivasi mereka sepanjang pembelajaran dalam talian di kediaman mereka. Seterusnya, kajian oleh Meeter (2020) yang dijalankan di Amsterdam mendapati bahawa motivasi pelajar lebih rendah berbanding sebelum kemunculan Covid-19. Namun terdapat segelintir pelajar IPT yang menyokong pembelajaran norma 
baharu ini atas sebab tidak perlu bergerak ke lokasi tertentu dan tidak terikat dengan peraturan institusi. Oleh demikian pelajar mempunyai masa terluang yang lebih banyak dan masa tersebut boleh dipenuhkan dengan ulang kaji. Hal ini disokong oleh kajian Gonzales at al. (2020) di Spain yang melihat pembelajaran dalam talian dengan bantuan peranti digital, melaporkan pelajar IPT lebih banyak mengulang kaji pelajaran daripada sebelumnya. Oleh itu, kajian berkaitan motivasi penting untuk dikaji memandangkan kaedah pembelajaran yang telah berubah.

\section{Akses Internet}

Internet merupakan sistem yang digunakan secara menyeluruh di seluruh dunia yang didatangi dengan pelbagai jenis rangkaian oleh pelbagai pihak swasta, awam, pendidikan, akademik, perniagaan dan juga rangkaian kerajaan. Akses internet dapat diertikan sebagai penghubung antara peranti teknologi dengan maklumat di media sosial tanpa mengira batas masa dan waktu (Mohd Fuad et al., 2012). Kemudahan akses Internet ini membantu individu dalam menyelesaikan sesuatu tugasan atau memperoleh pelbagai maklumat daripada pelbagai sumber yang diinginkan. Internet digunakan secara menyeluruh bukan sahaja dalam sektor pendidikan malah sektor perniagaan dan juga politik.

Merujuk laporan Jabatan Perangkaan Malaysia, penggunaan Internet di Malaysia telah meningkat daripada 21\% pada tahun 2009 kepada 90\% pada tahun 2019 (Rachel, 2020). Namun, pada tahun yang sama, hanya $8 \%$ daripada pengguna jalur lebar mempunyai capaian Internet yang baik dan dipercayai (MCMC, 2020).

Beberapa dapatan kajian lepas menunjukkan isu akses internet merupakan halangan besar yang dihadapi oleh pelajar IPT semasa menjalani pembelajaran dalam talian sepanjang pandemik Covid-19 (Chung \& Getha, 2020; Chung et al., 2020). Kajian Chung dan Getha (2020) yang menggunakan instrumen Online Readiness Scale (OLRS) di Malaysia menunjukkan 59\% daripada pelajar IPT bersetuju bahawa akses internet merupakan cabaran utama mereka dalam menghadapi pembelajaran dalam talian. Dapatan ini seiring dengan dapatan kajian Chung et al. (2020) iaitu cabaran terbesar pelajar di Malaysia semasa pembelajaran dalam talian ialah jaringan internet yang rendah dan data broadband yang terhad. Namun Khadijah et al. (2020) menyatakan isu akses internet ini boleh ditangani dengan segera jika pihak kerajaan dan telekomunikasi mengambil langkah yang proaktif. Oleh itu kajian berkenaan akses internet ini perlu memandangkan ia memberikan impak kepada proses pembelajaran dalam talian pelajar.

\section{Sosioekonomi}

Sosioekonomi merupakan istilah yang digunakan bagi mewakili elemen kemasyarakatan (sosial) dan ekonomi (Ummi et al., 2018). Peningkatan sosioekonomi sesebuah masyarakat mampu meningkatkan kemampuan mereka dalam menyediakan fasiliti keperluan yang sepatutnya. Tahap sosioekonomi atau kelas sosial individu dapat dikelaskan berdasarkan beberapa faktor seperti kemahiran, minat dan kekayaan. Tahap sosioekonomi lazimnya diukur melalui tiga faktor utama iaitu pendapatan, pekerjaan dan pendidikan. Berdasarkan Jabatan Perangkaan Malaysia (2020) tahap sosioekonomi rakyat di ukur melalui pendapatan isi rumah dan dikelaskan kepada tiga tahap iaitu: i) B40 (Bottom 40) kumpulan yang berpendapatan bawah RM 4, 850; ii) M40 (Middle 40) kumpulan yang pendapatan antara RM 4. 851 hingga RM 10, 970; iii) kumpulan T20 (Top 20) yang pendapatan RM 10, 971 dan ke atas.

Beberapa kajian lepas telah melihat faktor sosioekonomi keluarga semasa pembelajaran dalam talian dilaksanakan (Awal et. al, 2021; Nor Musfirah, 2021; Mahiswaran et al., 2020). Sosioekonomi keluarga dilihat memainkan peranan penting dalam menyediakan kemudahan pembelajaran dalam talian seperti peranti elektronik dan capaian Internet yang baik. Kekurangan suasana yang kondusif seperti ruang belajar yang selesa juga menyebabkan proses pembelajaran pelajar terganggu. Oleh itu kajian ini ingin melihat tahap sosioekonomi keluarga pelajar memandangkan ia memberikan kesan kepada kesediaan kemudahan yang diperlukan. 


\section{Metod Kajian}

\section{Reka Bentuk Kajian}

Kajian ini merupakan kajian berbentuk deskriptif dan inferensi yang menggunakan data kuantitatif untuk melihat tahap motivasi berdasarkan akses internet dan sosioekonomi keluarga pelajar. Data dikumpulkan melalui soal selidik secara dalam talian. Kaedah kuantitatif ini digunakan bagi memperoleh data yang bersifat statistik daripada sumber kajian dan kerap digunakan dalam bidang ilmu sains sosial. Teknologi yang kian berkembang semakin memudahkan pengaplikasian kaedah ini dengan mengedarkan soal selidik tanpa mengira batas tempat, masa dan waktu. Menurut Azzamurni (2020), pengumpulan data berdasarkan kaedah edaran soal selidik ini lebih mudah dan sesuai dengan situasi masa kini.

\section{Lokasi Kajian}

Kajian ini memilih kolej komuniti di daerah Bentong, Pahang sebagai lokasi kajian. Kolej ini dibina pada awal Mac 2003 dan awalnya dikenali sebagai Sekolah Menengah Teknik. Setelah dinaikkan taraf kepada kolej komuniti, kolej ini semakin dikenali dan telah menjadi pilihan pelajar di sekitar kawasan Bentong. Kolej komuniti merupakan sejenis institusi TVET (Technical and Vocational Education and Training) yang kini semakin meningkat dan memainkan peranan yang penting bagi melahirkan graduan mahir yang diinginkan pasaran. Bidang usahawan dilihat kian meningkat pada masa kini telah menunjukkan pentingnya pembangunan bidang usahawan di peringkat IPT terutama kolej komuniti. Selain itu, kolej komuniti ini mengetengahkan aktiviti Pembelajaran Sepanjang Hayat (PSH) kolej komuniti yang dilihat mampu memberi manfaat kepada komuniti sekeliling.

\section{Populasi dan Persampelan Kajian}

Populasi kajian ini terdiri daripada pelajar Kolej Komuniti Bentong yang mengikuti kursus dalam empat jenis program sijil kemahiran iaitu Sijil Teknologi Elektrik, Sijil Teknologi Maklumat, Sijil Pengoperasian Peniagaan dan Sijil Teknologi Pembinaan Bangunan. Secara keseluruhannya populasi kajian ini ialah 192 orang pelajar. Kaedah persampelan rawak mudah telah digunakan bagi memastikan setiap pelajar mempunyai peluang yang sama untuk dipilih sebagai sampel (Kamarul, 2015). Menurut jadual Krejcie dan Morgan (1970), bilangan sampel sepatutnya daripada populasi ini ialah seramai 127 orang pelajar.

\section{Instrumen Kajian}

Kajian ini menggunakan soal selidik sebagai instrumen kajian. Borang soal selidik ini mengandungi dua bahagian yang perlu dilengkapkan oleh sampel iaitu bahagian A: Maklumat Demografi, Akses Internet, Sosioekonomi dan bahagian B: Motivasi.

\section{Bahagian A: Maklumat Demografi}

Bahagian ini mengandungi soal berkaitan latar belakang responden seperti umur, jantina, bangsa, sijil kemahiran yang diambil, semester semasa dan tempat tinggal. Kajian ini memfokuskan kepada akses internet dan sosioekonomi pelajar. Oleh demikian beberapa soalan yang berkaitan akses internet dan sosioekonomi telah ditambah di bahagian ini.

\section{Bahagian B: Motivasi}

Bahagian ini menggunakan instrumen MSLQ iaitu Motivated Strategies Learning Questionnaire oleh Bill dan Paul (1991). Instrumen ini telah dibangunkan untuk menilai motivasi pelajar kolej dan strategi pembelajaran mereka. Instrumen ini mempunyai dua bahagian berasingan pertamanya ialah berkenaan motivasi, keduanya berkenaan strategi pembelajaran. Kerana kajian ini hanya memfokuskan kepada motivasi, pengkaji telah mengambil soal selidik yang berkaitan motivasi sahaja untuk diedarkan kepada 
sampel kajian. Bahagian motivasi dalam MSLQ ini mempunyai 31 item (Motivated Strategies for Learning Questionnaire Manual, 1991).

Instrumen ini menggunakan skala likert 7 (sangat tidak betul kepada saya - sangat betul kepada saya). Min skor bagi MSLQ ini terbahagi kepada tiga tahap, tinggi $(\mathrm{min}=5.01-7.00)$, sederhana ( $\min 3.01$ 5.00), dan rendah (min=1.00-3.00). Pelajar perlu menjawab ikut kesesuaian mereka terhadap soalan tersebut. Instrumen ini mengambil masa 20 hingga 30 minit untuk pelajar menjawabnya. Instrumen ini mempunyai nilai kebolehpercayaan yang tinggi iaitu $a=0.95$.

Instrumen ini mempunyai enam dimensi utama. Pertamanya ialah motivasi intrinsik di mana bagi menilai faktor dalaman seperti minat pelajar dalam melaksanakan tugasan. Keduanya ialah motivasi ekstrinsik bagi menilai faktor luaran seperti pencapaian, hadiah, kejayaan, pujian dan saingan. Ketiga ialah nilai, bagi menilai kefahaman pelajar berkenaan menarik, kepentingan dan kegunaan sesuatu tugasan itu. Keempat ialah kawalan kepercayaan pembelajaran bagi menilai kepercayaan pelajar terhadap usaha untuk belajar akan memberi kesan yang positif kepada mereka. Kelima ialah expentancy bagi menilai aspek kejayaan dan keberkesanan diri (self-efficacy) pelajar. Keenam ialah ujian kebimbangan bagi menilai kognitif dan kekosongan pelajar seperti kebimbangan dalam pencapaian pembelajaran mereka. Jadual 1 menunjukkan dimensi dan bilangan item bagi MSLQ.

Jadual 1: Dimensi dan bilangan item bagi instrumen MSLQ

\begin{tabular}{lcc}
\hline Dimensi & Nombor item & Jumlah \\
\hline Motivasi intrinsik & B1, B16, B22, B24 & 4 \\
Motivasi ekstrinsik & B7, B11, B13, B30 & 4 \\
Nilai tugasan & B4, B10, B17, B23, B26, B27 & 6 \\
Kawalan kepercayaan pembelajaran & B2, B9, B18, B25 & 4 \\
Efikasi kendiri pembelajaran dan prestasi & B5, B6, B12, B15, B20, B21, B29, B31 & 8 \\
Kebimbangan ujian & B3, B8, B14, B19, B28 & 5 \\
\hline Keseluruhan motivasi & & 31 \\
\hline
\end{tabular}

\section{Prosedur Analisis Data (Analisis Deskriptif Dan Analisis Inferensi)}

Kajian ini menggunakan data berbentuk kuantitatif yang berbentuk deskriptif dan inferensi. Kedua-dua analisis ini berdasarkan soal selidik yang telah diedarkan. Statistik deskriptif dalam kajian seperti skala nominal iaitu peratus dan kekerapan yang merangkumi Bahagian A dan Bahagian B. Seterusnya statistik deskriptif pula ialah min, median dan mod bagi melihat serakan data yang diperoleh. Statistik ini digunakan pada Bahagian B untuk mengenal pasti tahap motivasi pelajar kolej komuniti sepanjang pembelajaran dalam talian semasa pandemik. Data yang diperoleh akan dianalisis menggunakan program Special Package for Social Sciences(SPSS) versi 26.

\section{Hasil Kajian}

\section{Demografi Responden}

Seramai 127 (64.15\%) sampel daripada populasi 192 orang pelajar telah menjawab soal selidik yang diedarkan melalui aplikasi google form. Data menunjukkan seramai 82 orang (64.6\%) responden kajian adalah lelaki, manakala 45 orang responden (35.4\%) adalah perempuan. Majoriti sampel kajian (123 orang, 96.9\%) berumur 18 hingga 21 tahun, dan 4 orang, ( $3.1 \%)$ berumur 22 hingga 25 tahun. Pecahan mengikut bangsa pula menunjukkan sebahagian besar sampel berbangsa Melayu (113 orang, 89\%), India (12 orang, 9.4\%) dan 2 orang sampel berbangsa Cina (1.6\%).

Daripada keseluruhan sampel, seramai 54 orang (42.5\%) merupakan pelajar tahun 2, 39 (30.7\%) sampel merupakan pelajar tahun 1 dan 34 (26.8\%) adalah pelajar tahun 3. Bagi pencapaian akademik terkini, seramai 58 orang (45.7\%) mempunyai CGPA 3.51 hingga 4.00, 56 orang (44.1\%) mempunyai CGPA 3.01 hingga 3.50 dan 13 orang (10.2\%) mempunyai CGPA 2.51 hingga 3.00. Bagi taburan bilangan isi 
DOI: https://doi.org/10.47405/mjssh.v6i11.1162

rumah, 67 orang $(52.8 \%)$ sampel mempunyai bilangan isi rumah empat hingga ke enam orang, 37 orang (29.1\%) mempunyai bilangan isi rumah satu hingga tiga orang. Selebihnya, 23 orang (18.1\%) mempunyai bilangan isi rumah seramai tujuh orang ke atas.

Bagi taburan jenis pekerjaan bapa, majoriti bapa pelajar bekerja sendiri (35.4\%), bekerja di sektor kerajaan $(25.2 \%)$, dan bekerja di sektor swasta $(18.9 \%)$. Terdapat bapa pelajar yang telah bersara (16 orang, $12.6 \%$ ), manakala seramai 10 orang $(7.9 \%)$ sampel menyatakan bahawa bapa mereka tidak mempunyai pekerjaan. Apabila pekerjaan ibu pula dianalisis, dapatan menunjukkan majoriti ibu tidak bekerja 69 orang (54.35), terdapat ibu sampel yang bekerja dengan sektor kerajaan (26 orang, 20.5\%), dan dengan sektor swasta (24 orang, 18.9\%). Seramai 5 orang (2.4\%) ibu sampel telah bersara.

100 orang $(78.8 \%)$ mempunyai pendapatan keluarga kurang daripada RM4849 iaitu mereka berada dalam golongan B40 (Bottom 40), diikuti 24 orang (18.9\%) dari golongan M40 (Middle 40) dengan pendapatan antara RM4850 hingga RM10959 dan 3 orang (1.4\%) dari golongan T20 (Top 20) yang berpendapatan RM10961 ke atas. Mengenai lokasi kediaman pula, majoriti sampel (60 orang, 47.2\%) tinggal di luar bandar, 48 orang (37.8\%) sampel tinggal di bandar dan 19 (15.0\%) orang sampel tinggal di pinggir bandar.

Seterusnya, bagi capaian sumber internet, 87 (68.5\%) orang sampel menggunakan data mudah alih, 51 orang (40.2\%) sampel menggunakan WiFi manakala 24 (18.9\%) orang sampel menggunakan prabayar bulanan. Kurang dari setengah sampel mempunyai capaian internet yang baik (59 orang sampel, $46.5 \%), 36$ orang (28.3\%) sampel mempunyai capaian internet yang sederhana dan $32(25.2 \%)$ orang sampel mempunyai capaian internet yang sangat baik.

Mengenai peranti yang digunakan pula, 107 (84.3\%) orang sampel menggunakan telefon bimbit manakala hanya seorang (8\%) sampel menggunakan tablet, $12(9.4 \%)$ orang sampel menggunakan komputer, dan $84(66.1 \%)$ orang sampel menggunakan komputer riba. Bagi taburan penggunaan platform, $108(85.0 \%)$ orang sampel menggunakan Google Meet, manakala hanya $42(33.1 \%)$ orang sampel menggunakan Google Classroom.

Jadual 2: Demografi responden

\begin{tabular}{|c|c|c|c|}
\hline \multicolumn{2}{|l|}{ Pemboleh ubah } & Kekerapan (F) & Peratusan (\%) \\
\hline \multirow[t]{2}{*}{ Jantina } & Lelaki & 82 & 64.6 \\
\hline & Perempuan & 45 & 35.4 \\
\hline \multirow[t]{2}{*}{ Umur } & 18-21 tahun & 123 & 96.9 \\
\hline & $22-25$ tahun & 4 & 3.1 \\
\hline \multirow[t]{3}{*}{ Bangsa } & Melayu & 113 & 89.0 \\
\hline & India & 12 & 9.4 \\
\hline & Cina & 2 & 1.7 \\
\hline \multirow[t]{3}{*}{ Tahun pengajian } & Tahun 1 & 39 & 30.7 \\
\hline & Tahun 2 & 54 & 42.5 \\
\hline & Tahun 3 & 34 & 26.8 \\
\hline \multirow[t]{3}{*}{ Keputusan (CGPA) } & $2.51-3.00$ & 13 & 10.2 \\
\hline & $3.01-3.50$ & 56 & 44.1 \\
\hline & $3.51-4.00$ & 58 & 45.7 \\
\hline \multirow[t]{3}{*}{ Bilangan isi rumah } & $1-3$ orang & 37 & 29.1 \\
\hline & $4-6$ orang & 67 & 52.8 \\
\hline & 7 orang ke atas & 23 & 18.1 \\
\hline \multirow[t]{5}{*}{ Pekerjaan bapa } & Kerajaan & 32 & 25.2 \\
\hline & Swasta & 24 & 18.9 \\
\hline & Bekerja sendiri & 45 & 35.4 \\
\hline & Pesara & 16 & 12.6 \\
\hline & Tidak bekerja & 10 & 7.9 \\
\hline \multirow[t]{2}{*}{ Pekerjaan ibu } & Kerajaan & 26 & 20.5 \\
\hline & Swasta & 5 & 3.9 \\
\hline
\end{tabular}


DOI: https://doi.org/10.47405/mjssh.v6i11.1162

\begin{tabular}{llll} 
& Bekerja sendiri & 24 & 18.9 \\
& Pesara & 3 & 2.4 \\
Pendapatan keluarga & Tidak bekerja & 69 & 54.3 \\
& B40 & 100 & 78.7 \\
& M40 & 24 & 18.9 \\
& T20 & 3 & 2.4 \\
Sumber Internet & Bandar & 48 & 37.8 \\
& Luar bandar & 60 & 47.2 \\
Capaian Internet & Pinggir Bandar & 19 & 15.0 \\
& Data mudah alih & 87 & 68.5 \\
& Pra bayar bulanan & 24 & 18.9 \\
& WiFi & 51 & 40.2 \\
& Sangat baik & 32 & 25.2 \\
& Baik & 59 & 46.5 \\
& Sederhana & 36 & 28.3 \\
& Komputer & 12 & 9.4 \\
Platfom & Komputer riba & 84 & 66.1 \\
& Tablet & 1 & .8 \\
& Telefon bimbit & 107 & 84.3 \\
& Zoom & 102 & 80.3 \\
& Microsoft teams & 59 & 46.5 \\
& Google meet & 108 & 85.0 \\
& Google classroom & 42 & 33.1 \\
& WhatApps & 83 & 65.4 \\
\hline
\end{tabular}

\section{Tahap motivasi pelajar}

Analisis deskriptif dijalankan untuk mendapatkan min keseluruhan, min mengikut konstruk dan tahap motivasi responden kajian. Jadual 3 menunjukkan yang tahap motivasi sampel secara keseluruhan adalah tinggi $(\mathrm{min}=5.42)$. Semua konstruk yang diuji berada pada tahap yang tinggi. Konstruk yang tertinggi ialah motivasi ekstrinsik $(\min =5.79)$ manakala konstruk terendah ialah ujian kebimbangan $(\min =5.23)$.

Jadual 3: Tahap Motivasi Responden mengikut Konstruk

\begin{tabular}{llll}
\hline Konstruk & Kekerapan $(\boldsymbol{f})$ & Min & Tahap \\
\hline Motivasi Intrinsik & 127 & 5.19 & Tinggi \\
Motivasi Ekstrinsik & 127 & 5.79 & Tinggi \\
Nilai tugas & 127 & 5.45 & Tinggi \\
Kawalan kepercayaan pembelajaran & 127 & 5.53 & Tinggi \\
Efikasi kendiri pembelajaran dan prestasi & 127 & 5.39 & Tinggi \\
Ujian kebimbangan & 127 & 5.23 & Tinggi \\
\hline Keseluruhan & $\mathbf{1 2 7}$ & $\mathbf{5 . 4 2}$ & Tinggi \\
\hline
\end{tabular}

\section{Perbezaan Tahap Motivasi Berdasarkan Jantina dan Pencapaian Akademik Semasa Pembelajaran dalam Talian Sepanjang Pandemik}

Hipotesis Nul 1: Tidak terdapat perbezaan yang signifikan tahap motivasi berdasarkan jantina dalam kalangan pelajar kolej komuniti semasa pembelajaran dalam talian sepanjang pandemik Covid-19.

Jadual 4 menunjukkan perbezaan tahap motivasi berdasarkan jantina. Analisis menunjukkan min bagi jantina lelaki ialah 5.40, manakala min bagi perempuan pula ialah sebanyak 5.45. Berdasarkan jadual 4 wujud perbezaan yang signifikan $(\mathrm{t}=-.39, \mathrm{p}=0.047)$. Oleh itu hipotesis nul $(\mathrm{Ho})$ ditolak. Maka terdapat 
DOI: https://doi.org/10.47405/mjssh.v6i11.1162

perbezaan yang signifikan tahap motivasi berdasarkan jantina dalam kalangan pelajar kolej komuniti semasa pembelajaran dalam talian sepanjang pandemik covid-19. $(\mathrm{p}<0.05)$

Jadual 4: Perbezaan tahap motivasi pelajar berdasarkan jantina $(n=127)$

\begin{tabular}{lllllll}
\hline & Jantina & N & Min & SP & t & P \\
\hline \multirow{2}{*}{ Motivasi } & Lelaki & 82 & 5.40 & .64 & -.39 & .047 \\
& Perempuan & 45 & 5.45 & .79 & & \\
\hline
\end{tabular}

Hipotesis Nul 2: Tidak terdapat perbezaan yang signifikan tahap motivasi berdasarkan pencapaian akademik dalam kalangan pelajar kolej komuniti semasa pembelajaran dalam talian sepanjang pandemik Covid-19.

Bagi melihat perbezaan tahap motivasi berdasarkan pencapaian pelajar, analisis ANOVA sehala telah dijalankan. Berdasarkan jadual 5, didapati tidak terdapat perbezaan yang signifikan tahap motivasi berdasarkan pencapaian akademik dalam kalangan pelajar kolej komuniti sepanjang pembelajaran dalam talian semasa pandemik Covid-19, p=.385 (f $(2,124)=.962, \mathrm{p}>.05$ ). Maka hipotesis nul (Ho) gagal ditolak

Jadual 5: Perbezaan tahap motivasi berdasarkan pencapaian pelajar

\begin{tabular}{llllll}
\hline Punca Varian & JKD & dk & MKD & F & Sig.P \\
\hline Motivasi (MSLQ) & & & & & \\
Antara Kumpulan & .922 & 2 & .46 & .962 & .385 \\
Dalam Kumpulan & 59.46 & 124 & .48 & & \\
Jumlah & 60.38 & 126 & & & \\
\hline
\end{tabular}

\section{Perbezaan Tahap Motivasi Berdasarkan Kelajuan Internet Semasa Pembelajaran dalam Talian Sepanjang Pandemik}

Hipotesis Nul 3: Tidak terdapat perbezaan yang signifikan tahap motivasi berdasarkan kelajuan internet dalam kalangan pelajar kolej komuniti semasa pembelajaran dalam talian sepanjang pandemik Covid19.

Jadual 6 menunjukkan tidak terdapat perbezaan yang signifikan tahap motivasi berdasarkan kelajuan internet dalam kalangan pelajar kolej komuniti sepanjang pembelajaran dalam talian semasa pandemik covid-19, $\mathrm{p}=.092(\mathrm{f}(2,124)=2.44, \mathrm{p}>.05)$. Oleh itu hipotesis nul $(\mathrm{Ho})$ gagal ditolak

Hipotesis Nul 4: Tidak terdapat perbezaan yang signifikan tahap motivasi berdasarkan pendapatan keluarga dalam kalangan pelajar kolej komuniti semasa pembelajaran dalam talian sepanjang pandemik Covid-19.

Jadual 6 juga menunjukkan tidak terdapat perbezaan yang signifikan tahap motivasi berdasarkan pendapatan keluarga dalam kalangan pelajar kolej komuniti sepanjang pembelajaran dalam talian semasa pandemik covid-19, $\mathrm{p}=.216(\mathrm{f}(2,124)=1.55, \mathrm{p}>.05)$. Maka hipotesis nul (Ho) gagal ditolak.

Hipotesis Nul 5: Tidak terdapat perbezaan yang signifikan tahap motivasi berdasarkan pekerjaan bapa dalam kalangan pelajar kolej komuniti semasa pembelajaran dalam talian sepanjang pandemik Covid19.

Jadual 6 menunjukkan terdapat perbezaan yang signifikan antara tahap motivasi pelajar berdasarkan pekerjaan bapa dalam kalangan pelajar kolej komuniti sepanjang mengikuti sesi pembelajaran atas talian semasa pandemik Covid-19, $\mathrm{p}=.016(\mathrm{f}(2,124)=3.17, \mathrm{p}<.05)$. Berdasarkan dapatan ini, hipotesis nul (Ho) ditolak 
Hipotesis Nul 6: Tidak terdapat perbezaan yang signifikan tahap motivasi berdasarkan pekerjaan ibu dalam kalangan pelajar kolej komuniti semasa pembelajaran dalam talian sepanjang pandemik Covid19.

Analisis ANOVA seterusnya mengukur tahap motivasi pelajar berdasarkan pendapatan ibu. Seperti yang dinyatakan dalam jadual 6 , terdapat perbezaan yang signifikan antara tahap motivasi pelajar berdasarkan pekerjaan ibu dalam kalangan pelajar kolej komuniti sepanjang mengikuti pembelajaran atas talian semasa pandemik Covid-19, p=.006 (f $(2,124)=3.79, \mathrm{p}<.05)$. Oleh itu, hipotesis nul (Ho) ditolak.

Jadual 7 menunjukkan keputusan ujian Post Hoc Turkey bagi perbezaan antara faktor pekerjaan ibu dengan tahap motivasi. Dapatan ini menunjukkan pekerja swasta dan tidak bekerja mempunyai perbezaan min $=-1.14$, ralat piawai $=.33$ dan nilai signifikan .033 yang lebih kecil daripada nilai .05 $(\mathrm{p}<.05)$. Manakala tidak bekerja dan pekerja swasta mempunyai perbezaan $\min =1.16$, ralat piawai $=$ .31 dengan nilai signifikan .yang 003 lebih kecil daripada nilai .05 ( $\mathrm{p}<.05)$.

Jadual 6: Tahap motivasi pelajar berdasarkan kelajuan internet dan sosioekonomi

\begin{tabular}{|c|c|c|c|c|c|c|}
\hline & $\begin{array}{l}\text { Punca } \\
\text { Varian }\end{array}$ & JKD & $\mathbf{d k}$ & MKD & $\mathbf{F}$ & Sig \\
\hline \multirow[t]{3}{*}{$\begin{array}{l}\text { Kelajuan } \\
\text { internet }\end{array}$} & $\begin{array}{l}\text { Antara } \\
\text { Kumpulan }\end{array}$ & 2.28 & 2 & 1.14 & 2.44 & .092 \\
\hline & $\begin{array}{l}\text { Dalam } \\
\text { Kumpulan }\end{array}$ & 58.10 & 124 & .47 & & \\
\hline & Jumlah & 60.38 & 126 & & & \\
\hline \multirow{4}{*}{$\begin{array}{l}\text { Pendapatan } \\
\text { keluarga }\end{array}$} & Antara & 1.47 & 2 & .74 & 1.55 & .216 \\
\hline & Kumpulan & & & & & \\
\hline & $\begin{array}{l}\text { Dalam } \\
\text { Kumpulan }\end{array}$ & 58.91 & 124 & .48 & & \\
\hline & Jumlah & 60.38 & 126 & & & \\
\hline \multirow[t]{3}{*}{ Pekerjaan bapa } & $\begin{array}{l}\text { Antara } \\
\text { Kumpulan }\end{array}$ & 5.68 & 2 & 1.42 & 3.17 & .016 \\
\hline & $\begin{array}{l}\text { Dalam } \\
\text { Kumpulan }\end{array}$ & 54.70 & 124 & .45 & & \\
\hline & Jumlah & 60.38 & 126 & & & \\
\hline \multirow[t]{3}{*}{ Pekerjaan ibu } & $\begin{array}{l}\text { Antara } \\
\text { Kumpulan }\end{array}$ & 6.67 & 2 & 1.67 & 3.79 & .006 \\
\hline & $\begin{array}{l}\text { Dalam } \\
\text { Kumpulan }\end{array}$ & 53.71 & 124 & .44 & & \\
\hline & Jumlah & 60.38 & 126 & & & \\
\hline
\end{tabular}

Jadual 7: Ujian Post Hoc Turkey

\begin{tabular}{lllll}
\hline Pekerjaan & & $\begin{array}{l}\text { Perbezaan } \\
\text { Min }\end{array}$ & $\begin{array}{l}\text { Ralat } \\
\text { Piawai }\end{array}$ & Sig \\
\hline Swasta & Tidak Bekerja & -1.14 & .33 & .035 \\
Tidak Bekerja & Swasta & 1.16 & .31 & .003 \\
\hline
\end{tabular}

\section{Perbincangan Kajian}

Dapatan kajian ini menunjukkan tahap motivasi pelajar berada pada tahap yang tinggi walaupun terpaksa menghadapi pembelajaran dengan norma baharu di samping Perintah Kawalan Pergerakan yang dikeluarkan oleh kerajaan. Hal ini mungkin kerana disebabkan pelajar tidak mempunyai isu untuk 
menjalani pembelajaran secara dalam talian dengan memiliki kemudahan dan peralatan yang sempurna seperti komputer, telefon bimbit dan capaian internet yang mencukupi. Selain itu melihat kepada konstruk motivasi ekstrinsik pelajar yang tinggi dalam kajian ini menunjukkan faktor luaran seperti pencapaian, hadiah, kejayaan, pujian dan saingan memberikan kesan yang positif kepada mereka. Hal ini mungkin kerana menerima sokongan dan dorongan, secara tidak langsung memperlihatkan usaha pensyarah itu sendiri dalam menggalakkan pelajar untuk melibatkan diri dalam pembelajaran atas talian. Hasil ini disokong oleh kajian Munirah et al. (2021) yang mendapati responden kajiannya masih mempunyai motivasi yang tinggi, dan berjaya menghadirkan diri mereka semasa pembelajaran dalam talian. Hasil ini dilihat kesan daripada kesediaan, penerimaan dan kemudahan yang dimiliki pada tahap yang tinggi. Jelas bahawa seiring dengan hasil kajian yang lain, pelajar kolej komuniti mempunyai motivasi ekstrinsik yang tinggi dalam pembelajaran dalam talian.

Seterusnya, kajian ini mendapati perbezaan yang signifikan antara tahap motivasi sampel berdasarkan jantina, di mana pelajar perempuan mempunyai tahap motivasi yang lebih tinggi berbanding pelajar lelaki. Keputusan kajian ini disokong oleh Mohd Syahid et al. (2018) dan Nur Syarafina et al. (2020) yang mempamerkan dapatan bahawa terdapat perbezaan yang signifikan antara tahap motivasi dengan jantina pelajar. Namun kedua-dua kajian tersebut menunjukkan pelajar lelaki lebih bermotivasi daripada pelajar perempuan.

Dapatan hasil kajian berkenaan tahap motivasi berdasarkan kelajuan internet menunjukkan hasil berbeza dengan kajian Nirfayanti dan Nurbaeti (2019) yang menyatakan kelancaran Internet semasa menghadiri kuliah dalam talian mampu meningkatkan motivasi pelajar. Akses internet yang baik membantu dalam keterlibatan pelajar serta penghasilan tugasan mereka. Motivasi pelajar juga dilihat meningkat apabila mereka mampu mendapatkan maklum balas dengan segera daripada pensyarah serta rakan semasa pembelajaran dalam talian. Realitinya akses internet di kawasan pedalaman masih terhad, oleh itu kaedah pembelajaran menjadi aspek utama dalam meningkatkan motivasi belajar (Abdul Aziz et al., 2020).

Seterusnya, dapatan kajian ini menunjukkan tidak terdapat perbezaan yang signifikan bagi tahap motivasi berdasarkan pendapatan keluarga. Namun, terdapat perbezaan yang signifikan pada tahap motivasi berdasarkan pekerjaan ibu bapa mereka. Hasil ini disokong oleh Putu et al. (2020) yang mendapati motivasi belajar pelajar berbeza antara ibu yang tidak bekerja dengan ibu yang bekerja. Hal ini mungkin kerana cara didikan, sokongan dan pertuturan yang digunakan oleh golongan ibu dalam membantu meningkatkan motivasi anak-anak. Selain itu ibu yang bekerja turut mempunyai pengalaman, pandangan serta pendapat yang lebih realistik secara tidak langsung menjadi model kepada pelajar. Status pekerjaan sememangnya mempengaruhi kemampuan ekonomi dalam menyediakan kemudahan bagi kelancaran proses pembelajaran dalam talian pelajar. Hal ini dinyatakan dalam kajian luar negara oleh Martjin Meeter et. al (2020) menyatakan motivasi pelajar sebelum pandemik adalah lebih baik berbanding sekarang. Perbezaan tahap motivasi ini jelas kelihatan antara pelajar yang mempunyai akses kepada kemudahan dan pelajar yang tidak mempunyai akses kepada kemudahan.

\section{Kesimpulan}

Secara keseluruhannya, kajian ini telah mengkaji akses internet, sosioekonomi dan tahap motivasi pelajar kolej komuniti. Hasil kajian jelas menunjukkan motivasi pelajar Kolej Komuniti Bentong adalah di tahap yang tinggi walaupun pembelajaran dijalankan dalam talian sepanjang pandemik Covid-19. Dapatan ini menunjukkan yang kaedah pembelajaran yang digunakan mempunyai standard yang tinggi dan mampu berkembang seiring dengan perubahan dunia.

Pengkaji telah mengenali beberapa kekangan sepanjang kajian ini dijalankan, pertamanya kesukaran mendapatkan maklum balas daripada sampel kajian kerana data dikumpulkan secara dalam talian dan mengehadkan interaksi antara pengkaji dengan sampel kajian. Seterusnya, pengkaji hanya memfokuskan kepada sebuah kolej komuniti sahaja dan populasi yang agak kecil. Pengkaji akan datang dicadangkan untuk memperluaskan kajian dengan membuat perbandingan antara kolej komuniti untuk memperoleh sampel yang mempunyai latar belakang yang berbeza terutama dari segi umur. Selain itu 
pengkaji seterusnya juga dicadangkan untuk memperluaskan konsep kajian dengan membuat perbandingan antara kolej komuniti. Kajian-kajian ini sangat penting kerana dapat memberikan peluang dan membantu penambahbaikan kaedah pembelajaran dan kaedah baharu yang dapat diaplikasikan di dalam dunia pendidikan kini.

Hasil kajian ini juga dapat memberikan maklumat berkenaan motivasi belajar kepada pelajar, pensyarah dan institusi Kolej Komuniti Bentong di samping memahami situasi pandemik. Pelajar khususnya dapat memahami konsep motivasi dan kepentingannya dalam kehidupan seharian, terutamanya dalam pembelajaran mereka. Seterusnya pensyarah sendiri akan jelas dengan keadaan dan kekangan yang dihadapi oleh sesetengah pelajar, maka perancangan yang teliti perlu dilaksanakan bagi menghasilkan pembelajaran dalam talian yang bermakna. Pihak kolej secara tidak langsung dapat menyediakan aktiviti, kempen atau ceramah yang bersesuaian bagi meningkatkan motivasi pelajar. Ini dapat memastikan graduan yang berkualiti dapat dilahirkan. Secara tidak langsung, aktiviti yang dijalankan dapat menggalakkan pelajar untuk bergiat aktif dan menjana perhubungan yang baik antara pelajar dan pensyarah. Interaksi memainkan peranan penting dalam mengekalkan tahap motivasi pelajar (Mahiswaran et al., 2020). Diharapkan kajian ini dapat memberi idea dan menjadi panduan kepada mana-mana pihak yang memerlukan bagi berhadapan dengan norma baru yang perlu dijalani oleh setiap lapisan masyarakat yang terkesan akibat pandemik Covid-19.

\section{Rujukan}

Abdul Aziz Ishak \& Aida Zuraina Mir Ahmad Talaat. (2020). Pembelajaran Atas Talian: Tinjauan Terhadap Kesediaan Dan Motivasi Dalam Kalangan Pelajar Diploma Logistic Dan Pengurusan Rantaian Bekanalan, Politeknik Seberang Perai, Pulau Pinang. Jurnal Dunia Pendidikan, 2(4): 68-82.

Ahmad Alif Kamal, Norhunaini, Mohd Shipullah, Liyana Truna, Muna Sabri \& Syahrul N. Junaini. (2020). Transitioning to Online Learning During COVID-19 Pendemic: Case Study of a PreUniversity Centre in Malaysia. (IJACSA) International Journal of Advanced Computer Science and Application, 11(6): 217-223.

Ajmal, M., \& Ahmad, S. (2019). Exploration Of Anxiety Factors Among Students Of Distance Learning: A Case Study Of Allama Iqbal Open University. Bulletin Of Education And Research, 41(2), 67-78.

Alhaadi Ismail \& Norimah Zakaria. (2019). Faktor Yang Mempengaruhi Motivasi Pembelajaran Bahasa Melayu dalam Kalangan Murid di SJKC Chung Hwa Teluk Kemang. International Journal of The Malay World and Civilisation, 7(3): 23-30.

Alison Andrew, Sarah cattan, Monica Costa Dias, Christine Farquharson, Lucy Kraftman, Sonya Krutikova, Angus Phimister \& Almudena Sevilla. 2020. Learning During The Lockdown: RealTime Data on Children's Experiences during Home Learning. The Institute for Fiscal Studies: UK.

Awal Bahasoan, Wulan Ayuandiani, Muhammad Mukhram \& Aswar Rahmat. (2021). Effectivesness of Online Learning In Pandemic Covid-19. International Journal of Science, Technology \& Management.

Azman, N., \& Abdullah, D. (2021). A critical analysis of Malaysian Higher Education Institutions' response towards Covid-19: sustaining academic program delivery. Journal of Sustainability Science and Management, 16(1), 70-96.

Azzamurni Moktar \& Aini Hazrin Ahmad Anuar. (2020). Penggunaan Internet Di Dalam Mempertingkatkan Proses Pengajaran \& Pembelajaran (P\&P) Dalam Kalangan Pelajar, Jabatan Perdagangan, Politeknik Sultan Abdul Halim Mu'adzam Shah. Journal on Technical and Vocational Education (JTVE), 5(1), 0128-0821.

Chung, E., Noor, N. M., \& Vloreen Nity Mathew. (2020). Are You Ready? An Assessment of Online Learning Readiness among University Students. International Journal of Academic Research in Progressive Education and Development, 9(1), 301-317.

Ellen Chung, Geetha Subramaniam \& Laura Christ Dass. (2020). Online Learning Readiness Among University Students in Malaysia Amidst Covid-19. Asian Journal of University Education (AJUE), 16(2), 45-58. 
Malaysian Journal of Social Sciences and Humanities (MJSSH), Volume 6, Issue 11, (page 1 - 14), 2021

DOI: https://doi.org/10.47405/mjssh.v6i11.1162

Gonzalez, T., de la Rubia, M. A., Hincz, K. P., Comas-Lopez, M., Subirats, L., Fort, S., \& Sacha, G. M. (2020). Influence of COVID-19 confinement in students' performance in higher education. arXiv preprint arXiv:2004.09545.

Khadijah Mukhtar, Kainat Javed, Mahwish Arooj \& Ahsan Sethi. (2020). Anvantafes, Limitation and Recommendattions for online learning during COVID-19 Pandemic Era. Pakistan Journal of Medical Sciences. doi: 10.12669/pjms.

Khairiah Afifah Sharudin. (2019). Pengaplikasian Kaedah Kuantitatif Dalam Kajian Sains Sosial Pada Era Tranformasi Teknologi. https://www.researchgate.net/publication/337591180

Krajcie \& Morgan. (1970). Determining Sampel Size for Research Activities. Educational and Psychological Measurement, 30, 607-610.

Laporan Tahunan. (2017). Kolej Komuniti Bentong, Kementerian Pendidikan Malaysia

Lin, E., \& Lin, C. H. (2015). The Effect of Teacher-Student Interaction on Students' Learning Achievement in Online Tutoring Environment. International Journal of Technical Research and Applications.

Mahathir Yahaya \& Wardatul Hayat Adnan. (2021). Cabaran Pelajar Melalui Kaedah Pembelajaran Atas Talian: Kajian Institusi Pengajian Tinggi Awam Malaysia. Journal of Media and Information Warfare, 14(1), 11-20.

Mahiswaran Selvanathan, Nir Atikah Mohamed Hussin \& Alyani Nor Azazi. (2020) Students Learning Experiences During COVID-19: Work From Home Period In Malaysia Higher Learning Instititions. Journal SAGE, 10(11), 1-10.

Malaysian Communications and Multimedia Commission (MCMC). (2019). Industry performance report 2018. Retrieved from https://www.mcmc.gov.my/skmmgovmy/media/General/pdf/Industry-PerformanceReport2018.pdf

Martijn Meeter, Simone Plak \& Relnout E. de Vries. 2020. College Students's Motivation and Study $\begin{array}{llll}\text { Results After } & \text { COVID-19 Stay-at-hoem }\end{array}$ https://www.researchgate.net/publication/346172498

Mazidah Musa \& Nor Aidawati Abdillah. (2021). Penggunaan Google Meet Dalam Proses Pengajaran Dan Pembelajaran Di Politeknik Sultan Mizan Zainal Abidin. International Journal of Modern Education, 3(8), 104-113.

Moawad, R. A. (2020). Online Learning during the COVID- 19 Pandemic and Academic Stress in University Students. Revista Romaneasca Pentru Educatie Multidimensionala, 12(2), 100-107.

Mohamad Arif Johari \& Sa'odah Ahmad. (2019). Persepsi Tekanan Akademik dan Kesejahteraan Diri di Dalam Kalangan Pelajar Universiti di Serdang, Selangor. EDUCATUM - Journal of Social Science (EJOSS), 5(1), 24.36.

Mohd Syahid Mohd Razali, Norlena Salamuddin, Mohdamad Fuad Shanizan Azmain \& Mohd Khairul Anwar Md Yusof. (2018). Stail Kepimpinan Jurulatih Aktiviti Luar dengan Tahap Motivasi Pelajar Universiti Kebangsaan Malaysia. Muallim Journal of Social Sciences and Humanities (MJSSH), 2(1): 28-39.

Mukhtar, N. N., Rosli, S. N. A., \& Taha, H. (2021). Kesan jenis pembelajaran dalam talian terhadap sikap, motivasi dan pencapaian pelajar bagi subjek Fizik. Journal of Science and Mathematics Letters, 9(1), 60-76.

Munirah Salleh, Mohd Faizal Jamaludin, Noor Syaheeda Mohd Safie \& Julia Mohd Yusof. (2021). Tinjauan Keberkesanan Pembelajaran Secara dalam Talian Ketika Pancemik Covid-19: Perspektif Pelajar Sains Kejuruteraan Ibrahim Sultan. Jurnal Dunia Pendidikan, 3(1), 374-384.

Nguyen, T. (2015). The Effectiveness of Online Learning: Beyond No Significant Difference and Future Horizons. MERLOT Journal of Online Learning and Teaching, 11(2); 309-319.

Noormalina Adenan \& Yusmarwati Yusof. (2019). Internet Usage among The Vocational College Student In Johor Towards Information And Communication Integration. International Journal of Heritage, Art and Multimedia, 2(6), 19-32.

Nor Musfirah Mohamad. (2021). Cabaran Pedagogi Norma Baharu Di Kolej Universiti Islam Perlis (KUIPs) Ketika Pandemik Wabak Koronavirus Covid-19. Jurnal Pengajian Islam, 14, 243-254.

Norhana Ahad, Mohammad Fahmi Abdul Hamid, Aslinda Mohd Noor \& Zazalli Lazin. (2020). Analisis Faktor Tekanan Yang Mempengaruhi Pelajar Kolej Komuniti Negeri Johor Ketika Perintah Kawalan Pergerakan. Jurnal Dunia Pendidikan, 2(3), 158-172. 
Nur Syarafina Abdul Rahman, Zainal Fitri Mohd Zakifli \& Ying-Leh Ling. (2020). Kepentingan Kemudahan Teknologi dan Motivasi Membentuk Kesedaran Pelajar dalam Pemembelajaran Digital. National Research Innovation Conference (NRICon 2020): Kuching Serawak.

Nur Syazana Abd Shukor \& Mohd Nasir Masroom. (2020). Gaya Pembelajaran dan Motivasi Dalam Kalangan Calon SPM Di Sebuah Sekolah Menengah Agama di Negeri Johor. Jurnal Kemanusiaan, 18(2), 77-90.

Paul R. Pintrich, David A. F. Smith, Teresa Garcia \& Wilbert J. McKeachie. (1991). A Manual for the Use of the Motivated Strategies for Learning Questionnaire (MSLQ). The Universiti of Michigan Ann Arbor, Michigan. 48109-1259,

Rachel Gong. (2020). Digital Inclusion: Assessing Meaningful Internet Connectivity in Malaysia. Kuala Lumpur: Kahazanah Reasearh Institute. License: Creative Commons Arttribution CC BY 3.0.

Siti Nurshahidah Sah Allam, Mohd Sufiean Hassan, Rosilawati Sultan Mohideen, Aini Faezah Ramlan \& Rusydi Mohd Kamal. (2020). Online Distance Learning Readiness During Covid-19 Outbreak Among Undergraduate Students. International Journal of Academic Research in Business and Social Sciences, 10(5), 642-657.

Sushmita Dutta \& Marzia Khatan Smita. (2020). The Impact of COVID-19 Pandemic on Tertiary Education in Bangladesh: Student's Perspectives. Open Journal of Social Sciences, 8, 53-68.

TH. Subra, Mohamad Ainuddin Iskandar Lee Abdullah \& Kala Devi. (2019). Pengaruh Sosioekonomi Keluarga Terhadap Keciciran Pelajar-pelajar India: Kajian Kes Di Daerah Kuala Muda Kedah. International Journal of Modern Trends in Social Sciences, 2(9), 77-91. 